\title{
The effect of parity number on the metabolism, inflammation, and oxidative status of dairy sheep during the transition period
}

\author{
A. Cabiddu, ${ }^{1 *} \odot$ M. Dattena, ${ }^{1}$ M. Decandia, ${ }^{1}$ G. Molle, ${ }^{1}$ V. Lopreiato, ${ }^{2} \odot$ A. Minuti, ${ }^{2} \odot$ and E. Trevisi $^{2} \odot$ \\ ${ }^{1}$ Agris Sardegna, Agricultural Research Agency of Sardinia Loc., Bonassai, 07040, Olmedo, Sassari, Italy \\ ${ }^{2}$ Department of Animal Sciences, Food and Nutrition, Faculty of Agriculture, Food and Environmental Science, \\ Università Cattolica del Sacro Cuore, via Emilia Parmense 84, 29122 Piacenza, Italy
}

\section{ABSTRACT}

The objective of this study was to evaluate whether dairy sheep during the transition period are affected by their parity numbers with regard to (1) body weight (BW), body condition score (BCS), and production performance (milk yield and composition) and (2) metabolic, inflammation, and stress biomarkers. For this purpose, 30 Sarda dairy ewes $[15$ primiparous (PRP) and 15 multiparous (MUP) ewes] were recruited on $\mathrm{d}$ 90 of gestation. Each group was homogeneous according to age, BW, and BCS. Sampling was carried out at $-60,-30,-7,0,+30$, and $+60 \mathrm{~d}$ from lambing. The MUP ewes showed a higher BW (46.32 vs. $38.71 \mathrm{~kg}$ ) and larger litter size (1.45 vs. $1.06 \mathrm{~kg}$ ) but a lower BCS (2.47 vs. 2.70) than the PRP ewes. Furthermore, the MUP ewes had lower concentrations of glucose (3.49 vs. $4.27 \mathrm{~mol} / \mathrm{L})$, cholesterol (1.63 vs. $1.81 \mathrm{mmol} / \mathrm{L})$, free fatty acids $(0.47$ vs. $0.62 \mathrm{mmol} / \mathrm{L})$, and triglycerides (0.22 vs. $0.25 \mathrm{mmol} / \mathrm{L}$ ) compared with PRP ewes. With regard to inflammation and oxidative stress parameters, the PRP group had higher haptoglobin (0.48 vs. 0.18 $\mathrm{g} / \mathrm{L}$ ) and paraoxonase (187.90 vs. $152.11 \mathrm{U} / \mathrm{L}$ ) activity than the MUP group. Overall, the MUP ewes were characterized by greater milk production performance and greater feed intake, resulting in a better energy balance, than the PRP ewes. Interestingly, these findings highlighted a different metabolic and inflammatory response over the transition period between PRP and MUP ewes, with the latter displaying lower concentrations of inflammatory-related biomarkers.

Key words: periparturient dairy sheep, metabolic profile, inflammation, stress condition

Received December 23, 2019.

Accepted May 4, 2020.

*Corresponding author: acabiddu@agrisricerca.it

\section{INTRODUCTION}

The peripartum period is one of the most challenging phases for dairy sheep because several infectious diseases and metabolic disorders, such as pregnancy toxaemia, hypocalcemia, and acute postparturient mastitis, occur during this period (Mavrogianni and Brozos, 2008). Animal management, with a particular emphasis on nutrition, could help reduce both the incidence of peripartum diseases and the annual rate of losses (deaths) in ewes, estimated to be around $5 \%$ of a total flock (Mavrogianni and Brozos, 2008). The metabolic profile could be a useful tool for investigating the possible inadequate adaptation of dairy sheep to conditions typical of extensive or semi-extensive production systems, such as those where Sarda sheep are reared. Previous studies often focused on the lactation period (Castillo et al., 2016); metabolic adaptations around lambing were less often investigated, particularly in ewes with different parities. This critical physiological phase has been widely investigated in dairy cows (Drackley et al., 2005; Bionaz et al., 2007; Loor et al., 2013; Lopreiato et al., 2019).

The potential DMI (Bocquier et al.,1988) in dairy sheep during the peripartum period varies significantly from 1.2 to $2.8 \mathrm{~kg} / \mathrm{d}$. Such changes mostly depend on BW and may affect production levels, such as litter size and milk yield (MY). In particular, the DMI range is greatly affected by parity. This finding led to the interest in devising and implementing an appropriate strategy for avoiding energy and protein nutritional imbalances, inflammation, and impairment of the immune system (Celi, 2010). During the peripartum period, ruminants are characterized by a condition of immune dysregulation (Lacetera et al., 2005; Crookenden et al., 2016; Trevisi and Minuti, 2018), which could be associated with the nutritional status (i.e., energy and protein deficiency; Celi, 2010; Bertoni and Trevisi, 2013). The importance of detecting an inflammatory process in ruminants during the peripartum by identifying changes in the concentrations of acutephase pro- 
teins (APP) has been reported by Bertoni and Trevisi (2013) and Heller and Johns (2015). Evidence shows that some inflammation biomarkers, such as paraoxonase $(\mathbf{P O N})$ and haptoglobin, are very sensitive in signaling the presence of pathophysiological conditions (e.g., serious diseases, endotoxins, proinflammatory cytokine challenges; Bionaz et al., 2007; Trevisi et al., 2015). Other parameters, such as albumin, also have been associated with the immune response (Matanovic et al., 2007; Saleh, 2008). Because the transition period is considered critical for dairy ruminants with regard to the dysregulation of the immune system (Acuti et al., 2012; Trevisi and Minuti, 2018; Minuti et al., 2020), several studies have focused on the link between oxidative stress inflammation and the ensuing acute-phase response (Celi, 2010; Trevisi et al., 2011). The capacity of reactive oxygen metabolites (ROMt) and antioxidants, measured, for example, as the ferric-reducing ability of plasma (FRAP), seems useful in detecting an oxidative response in ruminants. Interestingly, some breeding systems, such as pasture-based ones, have a high content of antioxidants from eating green grass (Gatellier et al., 2004; Descalzo et al., 2005), and they seem to have a more favorable chance of limited oxidative damage.

Although studies on grazing dairy sheep have been sporadic, there is great interest in increasing the knowledge of the adaptation of dairy ewes to the onset of lactation in terms of energy metabolism, inflammatory status, and oxidative stress, considering the relevant effect on health and milk production. These differences are not clear at present in dairy sheep with different parity numbers, because little data are available in the literature. Therefore, the objective of this study was to investigate the metabolic profile around the lambing period of Sarda dairy sheep with different parity numbers reared in semi-extensive systems.

\section{MATERIALS AND METHODS}

The experimental protocol and implemented procedures were in accordance with the ethical guidelines in force at Agris, in compliance with Directive 2010/63/ EU of the European Parliament and the Council of September 22, 2010 (European Commission, 2010), on the protection of animals used for scientific purposes. The study was performed at the Bonassai Research Station in the northwest region of Sardinia (40_3904600N, 8_2104600E; $33 \mathrm{~m}$ above sea level), which has a Mediterranean climate and an average rainfall of $569 \mathrm{~mm}$. The experiment on multiparous (MUP) sheep began in September 2012 (60 d before lambing) and ended in February 2013 (60 d after lambing), and the experi- ment on primiparous (PRP) sheep began at the end of December 2012 and ended in May 2013. The difference between the lambing periods of the MUP and PRP sheep was due to the different mating seasons for mature and young sheep in the Mediterranean basin (Todaro et al., 2015).

\section{Animal and Feeding Management}

In total, 30 Sarda dairy sheep entered the experiment on d 90 of gestation. The animals were divided into 2 groups according to their parity numbers: 15 MUP (age $4.02 \pm 0.35$ yr; parity $3.93 \pm 0.35$; live BW $46.2 \pm 0.8$ $\mathrm{kg}$; BCS $2.55 \pm 0.05$ ) and 15 PRP (age $1.08 \pm 0.01 \mathrm{yr}$; live BW $34.66 \pm 0.47 \mathrm{~kg}$; BCS $2.87 \pm 0.03$ ). Each group was split into 3 replicates of 5 ewes each. The ewes were fed indoors from $60 \mathrm{~d}$ before lambing until their weaning (30 d after lambing). The diets were formulated based on the average ewe's live weight, BCS, days from lambing, and age using the small ruminant nutrition system (Cannas et al., 2004; NRC, 2007; Tedeschi et al., 2008). For each experimental group, the energy and protein levels and macromineral balance were estimated every 2 wk and supplement levels were adjusted accordingly. To this end, during the stall-feeding phase the daily dose of hay was determined on the basis of measured levels of intake, and the concentrate levels were adjusted accordingly. In grazing lactating sheep, hay was rationed, and the concentrate levels were adjusted every $2 \mathrm{wk}$ on the basis of the total requirements and estimated herbage intake. This was first estimated ex post as the difference between potential intake and supplemental intake. Then it was predicted according to the empirical model (Molle, 2014) developed for sheep that graze part time, as described below. The lower of these 2 values was retained in the final calculation for cautionary purposes. During the experimental period, the ewes were fed ryegrass hay and concentrates offered in 2 meals, 1 in the morning $(0800 \mathrm{~h})$ and 1 in the afternoon $(1500 \mathrm{~h})$. The ingredients of the concentrates are reported in Table 1. After weaning, the ewes spent approximately $6 \mathrm{~h} / \mathrm{d}$ grazing on a plot of ryegrass and were machine-milked daily at 0800 and $1500 \mathrm{~h}$. Both groups received in their stalls $600 \mathrm{~g} \mathrm{DM} /$ sheep per day of hay and $500 \mathrm{~g} \mathrm{DM} /$ sheep per day of concentrate. The chemical compositions of the hay, concentrate, and herbage are shown in Table 1.

\section{Grazing and Pasture Mass Measurements}

The pasture was a newly established sward of Italian ryegrass (Lolium multiflorum Lam., cv. Teanna) sown in autumn on a flat clay-loam calcareous soil, low in 
Table 1. Chemical analysis (average $\pm \mathrm{SE}$ ) and nutritive value of diets fed to multiparous (MUP) or primiparous (PRP) ewes from -60 to 60 d from lambing

\begin{tabular}{|c|c|c|c|c|c|c|}
\hline Item $^{1}$ & \multicolumn{2}{|c|}{ Hay } & \multicolumn{2}{|c|}{ Concentrate $^{2}$} & \multicolumn{2}{|c|}{ Herbage } \\
\hline OM & $91.87 \pm 0.28$ & $92.33 \pm 0.83$ & $87.10 \pm 0.06$ & $87.23 \pm 0.46$ & $91.17 \pm 0.34$ & $84.51 \pm 0.52$ \\
\hline $\mathrm{NDF}$ & $59.82 \pm 2.23$ & $64.42 \pm 2.51$ & $32.62 \pm 0.41$ & $36.71 \pm 1.04$ & $56.61 \pm 0.70$ & $45.09 \pm 2.08$ \\
\hline $\mathrm{ADF}$ & $23.64 \pm 3.25$ & $37.61 \pm 1.53$ & $15.87 \pm 0.65$ & $19.62 \pm 0.50$ & $29.77 \pm 0.34$ & $20.24 \pm 0.79$ \\
\hline Ash & $8.13 \pm 0.28$ & $7.76 \pm 0.83$ & $12.90 \pm 0.06$ & $12.77 \pm 0.46$ & $8.92 \pm 0.42$ & $15.49 \pm 0.52$ \\
\hline $\mathrm{CP}$ & $9.23 \pm 2.48$ & $6.50 \pm 1.67$ & $24.30 \pm 0.11$ & $16.60 \pm 0.32$ & $10.85 \pm 0.86$ & $17.51 \pm 1.57$ \\
\hline $\mathrm{SP}, \%$ of $\mathrm{CP}$ & $24.29 \pm 1.64$ & $23.04 \pm 8.51$ & $33.70 \pm 0.11$ & $26.87 \pm 3.33$ & $41.09 \pm 2.16$ & $34.37 \pm 2.99$ \\
\hline ADIN, $\%$ of CP & $12.85 \pm 1.64$ & $16.04 \pm 3.64$ & $7.45 \pm 0.08$ & $9.19 \pm 1.11$ & $4.03 \pm 2.16$ & $8.64 \pm 1.16$ \\
\hline
\end{tabular}

${ }^{1} \mathrm{EE}=$ ether extract; $\mathrm{SP}=$ soluble protein.

${ }^{2}$ Ingredients of the PRP concentrate $(\mathrm{g} / \mathrm{kg}$ of DM) = soybean meal 220, wheat bran 200, sunflower meal 180, wheat screen 170 , corn gluten feed 70 , citrus byproducts 50 , calcium carbonate + premix + clay 80 , molasses 30 . Ingredients of the MUP concentrate $(\mathrm{g} / \mathrm{kg}$ of DM) $=$ dehydrated alfalfa 280 , wheat bran 275 , sunflower meal 120 , corn 106 , calcium carbonate + premix + clay 62 , molasses 50 , barley 47 , soybean meal 40 , beans 20 .

$\mathrm{P}_{2} \mathrm{O}_{5}$ content and with a $\mathrm{pH}$ of 8.0 using $40 \mathrm{~kg} / \mathrm{ha}$ of seed. A randomized block design with 3 replicate plots was used for each parity group. Each plot was 10,000 $\mathrm{m}^{2}$ divided into 4 subplots. The stocking rate for all groups was 10 ewe/ha. The subplots were grazed rotationally ( $7 \mathrm{~d}$ of occupation for each). The sward height was measured before and after grazing by a weighted plate grass meter (48 measurements/ha), and the herbage mass was estimated by cutting at ground level and weighing twelve $0.5-\mathrm{m}^{2}$ quadrats/ha. The growth and regrowth of herbage were measured using the grazing exclusion cages $(1 \times 1 \mathrm{~m})$ per subplot.

\section{Animal Measurements}

The animals' BW and BCS were recorded on $\mathrm{d}-60$, $-30,-7,0,+30$, and +60 from lambing. Blood samples were collected at $-60,-30,-7,0,+30$, and $+60 \mathrm{~d}$ from lambing time from the jugular vein into lithium heparin tubes (before the morning meal) and were immediately stored in iced water until centrifugation. Blood samples were centrifuged at $3,500 \times g$ for $15 \mathrm{~min}$ at $4^{\circ} \mathrm{C}$, and plasma samples were frozen $\left(-20^{\circ} \mathrm{C}\right)$ in several fractions until analysis. Blood metabolites were determined by an automated biochemistry analyzer (ILAB 650; Instrumentation Laboratory, Lexington, MA) in accordance with methods already described by Calamari et al. (2016) for the following parameters: glucose, free fatty acids (FFA), BHB, total cholesterol, triglycerides, total protein, creatinine, urea, haptoglobin, ceruloplasmin, PON, albumin, globulin, bilirubin, $\gamma$-glutamyl transferase (GGT), total ROMt, and FRAP.

The individual MY was measured every 2 wk after weaning at 30, 45, and $60 \mathrm{~d}$ after lambing. Milk samples were assayed for fat, proteins $(\mathrm{N} \times 6.38)$, SCC, and casein by using Milkoscan FT+ (Foss Electric, Hillerød, Denmark), and the urea was measured by differential pH-metry (CL-10 Micro, Eurochem, Ardea, Italy). The standard MY (SMY) was calculated according to the stipulations of Bocquier et al. (1993). Lambs were weighed at birth and then every week until weaning.

Forage and concentrate intakes of each replicate, within each group, were measured daily as the difference between offered and ort weights. The herbage DMI was calculated according to the following equation, validated for dairy sheep grazing part time on Mediterranean forages (Molle, 2014):

$$
\begin{aligned}
\mathrm{HDMI}= & 802.46+0.32 \mathrm{MY}-28.89 \mathrm{NDFH} \\
& +545.53 \mathrm{TA}-51.74 \mathrm{TA}^{2},
\end{aligned}
$$

where HDMI is the herbage intake ( $\mathrm{g}$ of DM), MY is the milk yield $(\mathrm{g} / \mathrm{d})$, NDFH is the NDF content of grazed herbage (\% DM), and TA is the time of access to pasture $(\mathrm{h} / \mathrm{d})$.

Forages, herbage, and concentrates and corresponding orts were sampled monthly and sequentially for 4 d for each replicate. Subsequently, replicate samples were pooled and stored at $-20^{\circ} \mathrm{C}$ until processing for further analysis. Forage samples were freeze-dried and then ground through a 1-mm screen before analysis. Crude protein and ether extract (EE) contents were determined according to AOAC International (2000). The NDF and ADF contents were determined using an Ankom fiber analyzer and the filter bag technique (Ankom Technology, Fairport, NY). Crude protein fractions (NPN, buffer soluble protein, and ADIN; Licitra 
et al., 1996) and water-soluble carbohydrates (Bailey, 1958) were also determined.

\section{Statistical Analyses}

A repeated-measures model was fitted to the data using PROC MIXED of SAS (version 9.4; SAS Institute Inc., Cary, NC). A variance-covariance structure was chosen based on the best Akaike information criterion and the Bayesian information criteria indices. Before the analysis, all data were tested for normal distribution by evaluating the Shapiro-Wilk statistics using the univariate SAS procedure. The mixed model included parity number, physiological stage (PS; days from lambing), and their interaction (parity $\times$ PS) as fixed effects, whereas ewes were included as a random effect. The diet's chemical composition, DMI, and ME and $\mathrm{MP}$ intakes, with $\Delta \mathrm{ME}$ and $\Delta \mathrm{MP}$ intake (calculated as differences between requirements and allowances), were analyzed by PROC GLM of SAS, considering the replicate groups (5 sheep/replicate) as experimental units. The model included parity, PS, and their interaction $($ parity $\times$ PS) as fixed effects. Statistical significance was declared at $P<0.05$ using the PDIFF statement in SAS.

\section{RESULTS}

\section{The Animals' Performance, Energy, and Protein Balance}

After lambing, the feed intake was higher in MUP ewes than PRP ewes at both time points, 30 and $60 \mathrm{~d}$ after lambing $(P<0.05$; Figure 1$)$. Likewise, ME intake $(\mathrm{MJ} / \mathrm{d}), \mathrm{MP}$ intake $(\mathrm{g} / \mathrm{d}), \Delta \mathrm{ME}$ (difference between energy intake and energy requirement), and $\Delta \mathrm{MP}$ (difference between MP intake and MP requirement) were affected by parity numbers $(P<0.01$; Supplemental Table S1, https://doi.org/10.3168/jds.2019-18114), with lower values in the MUP group than the PRP group during the pregnant period. The prepartum period showed higher values of BW compared with the postpartum period $(P<0.01$; Supplemental Figure S1, https://doi.org/10.3168/jds.2019-18114), with higher levels in the MUP group than in the PRP group for the whole period (Figure 2A). The BW rate increment was higher in PRP ewes than in MUP ones, starting from -60 to $-30 \mathrm{~d}$ from lambing (Supplemental Figure $\mathrm{S} 1 \mathrm{~A})$. The BCS was altogether higher in the PRP sheep than the MUP sheep (Figure 2B).

The twinship rate was $37 \%$ higher in the MUP group than the PRP group $(1.47$ vs. $1.07 \mathrm{~kg} ; P<0.01$ for the MUP group and PRP group, respectively; Figure
3). The lambs' performance was not affected by parity number in terms of daily gain; the daily gain by lambs was affected by the parity $\times$ PS $(P<0.01)$ interaction, with MUP lambs showing a higher gain at $19 \mathrm{~d}$ of age than PRP lambs (Figure 4B).

Both the MY (1,674 vs. 1,425 mL/d per head for the MUP group and PRP group, respectively) and SMY (1,441 vs. 1,126 mL/d per head for the MUP group and PRP group, respectively) were higher in MUP ewes than in PRP ones (parity; $P<0.05$ ). However, the MY and SMY, altogether, decreased from 45 to $60 \mathrm{~d}$ of lactation (PS; $P<0.05$ ). The fat, protein, and $\mathrm{CN}$ percentages in milk were higher in the MUP sheep than the PRP sheep $(P<0.01)$. The content of these components significantly changed with the PS $(P<0.01)$. The fat content increased during lactation in the MUP group, but it decreased in the PRP group. The protein and CN increased in both groups, but the MUP group had higher increments than the PRP group (parity $\times$ PS; $P<0.01$; Table 2). Interestingly, from 30 to $60 \mathrm{~d}$ after lambing, the CN content in the MUP milk increased by $15 \%$, but it increased by only $9 \%$ in the PRP milk $(P<0.05$; Table 2$)$. Although the SCC values showed relevant variability during the experimental period, no effect of parity number was detected (Table 2).

\section{Biomarkers of Energy and Liver Functionality}

Parity number significantly influenced the blood glucose concentration for the whole period. The MUP sheep showed a lower glucose concentration than PRP sheep (3.49 vs. $4.27 \mathrm{mmol} / \mathrm{L}$, respectively; $P<0.01$, average over time). After lambing, the plasma glucose

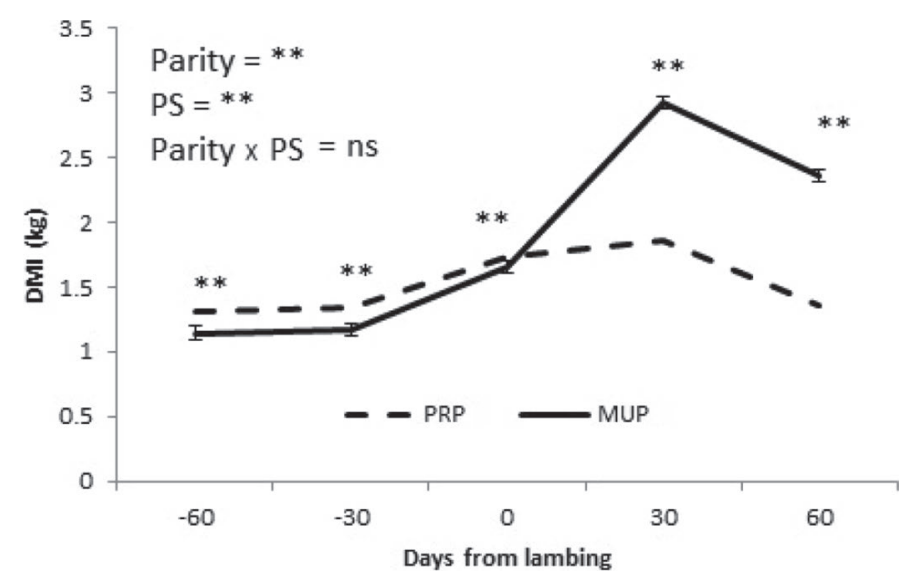

Figure 1. Means $( \pm$ SEM) of daily DMI during the experimental period in primiparous (PRP) and multiparous (MUP) ewes. PS = physiological stage. ${ }^{* *} P<0.01$ indicates a significant difference between parities. 

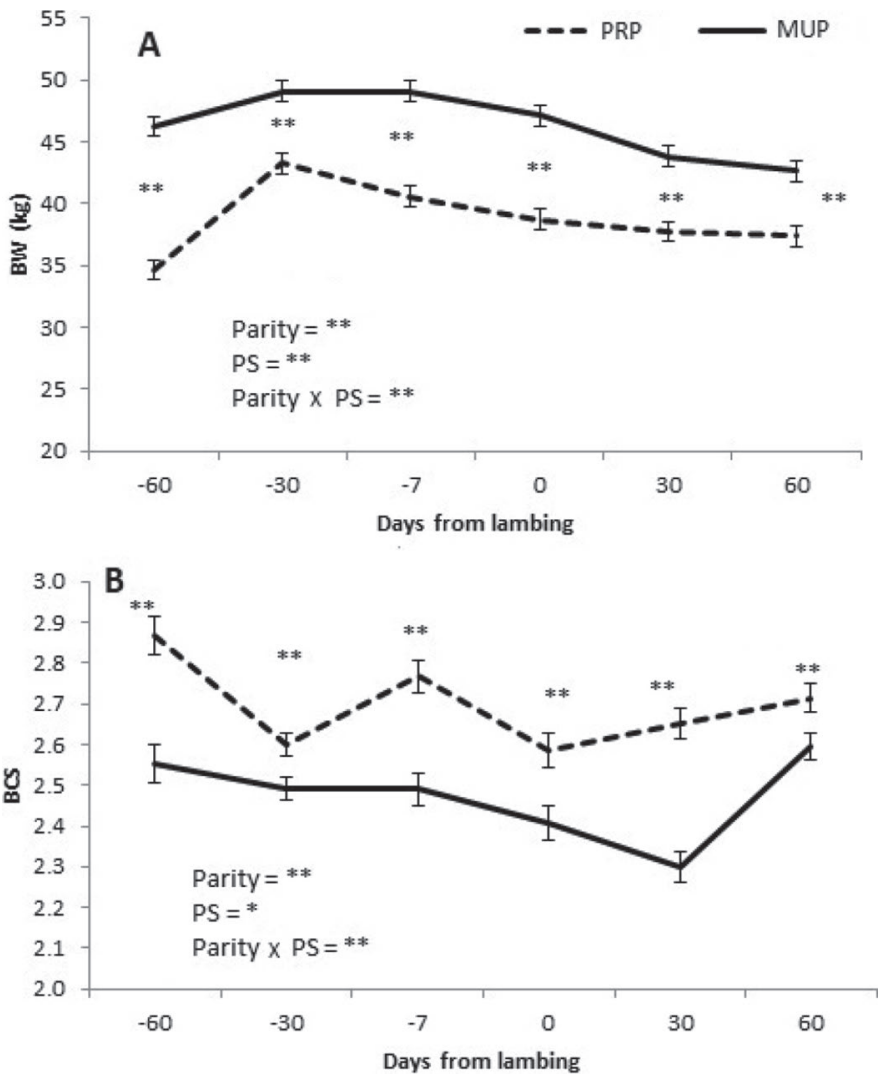

Figure 2. Means $( \pm \mathrm{SEM})$ of $(\mathrm{A}) \mathrm{BW}$ and $(\mathrm{B})$ BCS during the experimental period in primiparous (PRP) and multiparous (MUP) ewes. PS $=$ physiological stage. ${ }^{*} P<0.05$ and ${ }^{* *} P<0.01$ indicate significant differences between parities.

increased in MUP sheep, reaching $4.08 \mathrm{mmol} / \mathrm{L}$, but it remained almost constant in PRP sheep, so the difference between groups declined during lactation (PS; $P$ $<0.01$; Table 3).

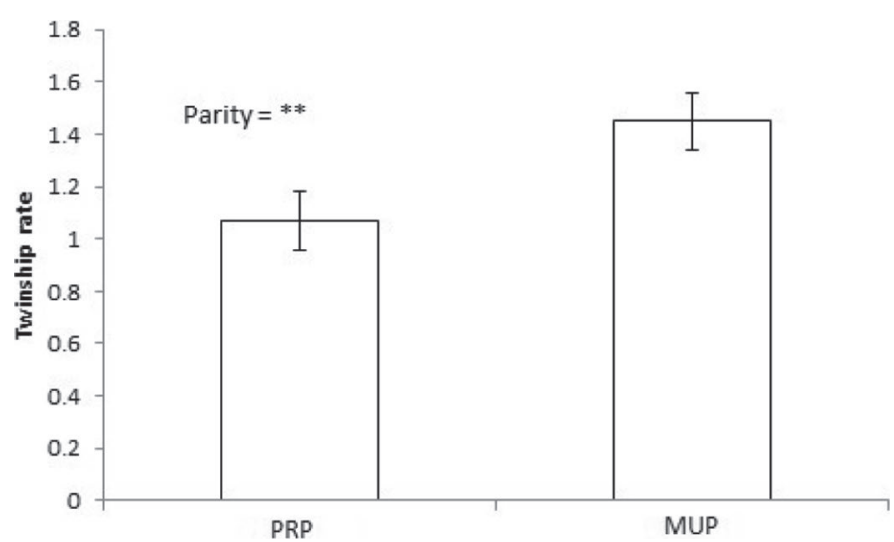

Figure 3. Means $( \pm$ SEM) of twinship rate in primiparous $(\mathrm{PRP})$ and multiparous (MUP) ewes. ${ }^{* *} P<0.01$ indicates a significant difference between parities.
Overall, the cholesterol concentration was lower in the MUP group than in the PRP group (1.63 vs. 1.81 mmol/L, respectively; $P<0.05$; average over time). Concentrations during pregnancy were almost constant and increased after lambing in both groups (PS; $P<$ 0.01; Table 3); however, the PRP group had higher values after lambing compared with the MUP group (parity $\times \mathrm{PS} ; P<0.01$ ).

The average FFA concentration (Table 3 ) was higher in PRP sheep than in MUP sheep (0.62 vs. 0.47 $\mathrm{mmol} / \mathrm{L}$, respectively; $P<0.01$; average over time).

The plasma BHB concentration did not show significant differences among parity groups and the PS. Nevertheless, the parity $\times$ PS interaction proved to be significant $(P<0.01$, Table 3$)$, likely because of the anticipated and prolonged increase of BHB in the PRP group around lambing.

In the whole period, the plasma triglycerides were affected by parity number, proving to be lower in MUP sheep than in PRP sheep (0.22 vs. $0.25 \mathrm{mmol} / \mathrm{L} ; P$ $<0.03$; average over time). After lambing, the plasma triglyceride concentration decreased in the PRP group
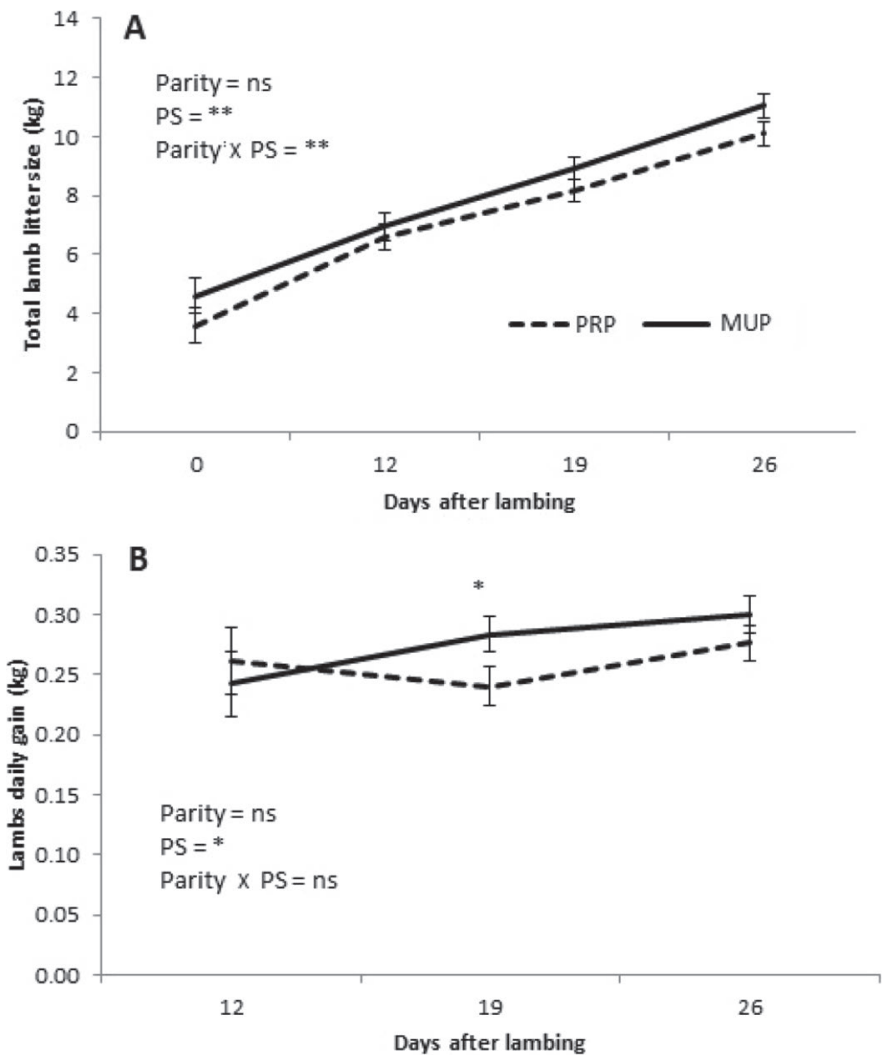

Figure 4. Means $( \pm \mathrm{SEM})$ of $(\mathrm{A})$ total lamb litter size and (B) lambs daily gain during the $30 \mathrm{~d}$ after lambing in primiparous (PRP) and multiparous (MUP) ewes. PS $=$ physiological stage. ${ }^{*} P<0.05$ and ${ }^{* *} P<0.01$ indicate significant differences between parities. 
Table 2. The effect (LSM) of parity number and physiological stage (PS) on milk yield (MY), standard milk yield (SMY) and milk composition in the first 2 mo of lactation in Sarda dairy ewes

\begin{tabular}{|c|c|c|c|c|c|c|c|c|}
\hline Item & Parity $^{1}$ & \multicolumn{3}{|c|}{ Days after lambing } & SEM & \multicolumn{3}{|c|}{$P$-value } \\
\hline $\mathrm{MY}, \mathrm{mL}$ & MUP & $1,755.13$ & $1,752.13$ & $1,561.33$ & 89.23 & & & \\
\hline \multirow{2}{*}{$\mathrm{SMY}, \mathrm{mL}$} & PRP & $1,154.44$ & $1,123.21$ & $1,098.95$ & 45.00 & $* *$ & $* *$ & NS \\
\hline & MUP & $1,445.55$ & $1,491.09$ & 1,387 & 74.61 & & & \\
\hline Fat, $\%$ & PRP & 5.59 & 5.17 & 5.13 & 0.13 & $* *$ & $* *$ & $* *$ \\
\hline Protein, \% & MUP & 4.68 & 5.18 & 5.28 & 0.13 & & & \\
\hline \multirow{2}{*}{$\mathrm{CN}, \%$} & PRP & 3.42 & 3.49 & 3.69 & 0.07 & $* *$ & $* *$ & ** \\
\hline & MUP & 3.64 & 4.09 & 4.17 & 0.11 & & & \\
\hline \multirow[t]{2}{*}{$\mathrm{SCC}, \times 10^{3}$ cells $/ \mathrm{mL}$} & PRP & 834 & 52 & 775 & 413 & NS & * & NS \\
\hline & MUP & 338 & 124 & 159 & 49 & & & \\
\hline
\end{tabular}

${ }^{1} \mathrm{PRP}=$ primiparous sheep; MUP $=$ multiparous sheep.

$* P<0.05$ and ${ }^{* *} P<0.01$.

(0.24 vs. $0.20 \mathrm{mmol} / \mathrm{L} ; P<0.02)$ compared with the MUP group, as reported in Table 3.

The MUP sheep showed a progressive reduction in plasma urea until lambing, followed by a sharp but temporary rise, whereas the PRP sheep showed a mild decrease in late pregnancy and a more prolonged increase after lambing. Overall, the plasma urea was not affected by parity, but significant effects for the PS and the parity $\times$ PS interaction $(P<0.01)$ were found (Table 3), given the different pattern of changes around lambing.

The plasma creatinine was also not affected by parity, though it showed a reduction after lambing in both groups (PS; $P<0.01$; Table 3 ). The MUP sheep had a more severe and prolonged reduction than the PRP sheep, and the parity $\times$ PS interaction reached the statistical level $(P<0.01)$.

More details on the energy biomarkers during preand postpartum are reported are reported in Supplemental Figure S2 (https://doi.org/10.3168/jds.2019 -18114).

The GGT plasma activity (Table 3) was higher in PRP sheep than in MUP sheep (69.30 vs. $59.93 \mathrm{U} / \mathrm{L}$; $P<0.01$ ) for the entire experimental period. Moreover, the GGT activity showed a slight increase during the postpartum period compared with the prepartum period

Table 3. Plasma biomarkers of energy metabolism and liver functionality (LSM) of primiparous (PRP) and multiparous (MUP) Sarda dairy ewes pre- and postpartum reared in a semi-extensive system

\begin{tabular}{|c|c|c|c|c|c|c|c|c|c|c|c|}
\hline Biomarker $^{1}$ & Parity & \multicolumn{6}{|c|}{ Days from lambing } & SEM & \multicolumn{3}{|c|}{$P$-value } \\
\hline Glucose, $\mathrm{mmol} / \mathrm{L}$ & PRP & 4.35 & 4.20 & 4.47 & 4.26 & 4.31 & 4.03 & 0.04 & $* *$ & $* *$ & $* *$ \\
\hline \multirow{2}{*}{ Cholesterol, mmol/L } & PRP & 1.77 & 1.63 & 1.80 & 1.62 & 1.80 & 2.26 & 0.03 & $*$ & $* *$ & $* *$ \\
\hline & MUP & 1.62 & 1.55 & 1.53 & 1.52 & 1.80 & 1.76 & 0.04 & & & \\
\hline $\mathrm{FFA}, \mathrm{mmol} / \mathrm{L}$ & PRP & 0.61 & 0.69 & 0.62 & 0.75 & 0.48 & 0.56 & 0.03 & ** & $* *$ & NS \\
\hline \multirow{2}{*}{ Triglycerides, mmol/L } & PRP & 0.24 & 0.27 & 0.28 & 0.24 & 0.26 & 0.20 & 0.01 & * & $* *$ & $* *$ \\
\hline & MUP & 0.16 & 0.21 & 0.29 & 0.23 & 0.24 & 0.22 & 0.01 & & & \\
\hline \multirow[t]{2}{*}{ Urea, mmol/L } & PRP & 7.07 & 5.93 & 6.26 & 6.89 & 9.15 & 5.66 & 0.17 & NS & $* *$ & $* *$ \\
\hline & MUP & 9.11 & 6.69 & 5.36 & 5.20 & 7.82 & 8.06 & 0.22 & & & \\
\hline \multirow[t]{2}{*}{ Creatinine, $\mu \mathrm{mol} / \mathrm{L}$} & PRP & 77.03 & 76.64 & 76.13 & 79.09 & 68.98 & 76.82 & 0.72 & NS & $* *$ & $* *$ \\
\hline & MUP & 68.03 & 80.82 & 78.07 & 77.26 & 69.44 & 68.24 & 0.99 & & & \\
\hline
\end{tabular}

${ }^{1} \mathrm{FFA}=$ free fatty acids; GGT $=\gamma$-glutamyl transferase.

${ }^{2} \mathrm{PS}=$ physiological stage.

${ }^{*} P<0.05$ and ${ }^{* *} P<0.01$ 
Table 4. Plasma biomarkers of positive acute-phase protein, negative acute-phase protein, and oxidative stress parameters (LSM) of primiparous (PRP) and multiparous (MUP) Sarda dairy ewes pre- and postpartum reared in a semi-extensive system

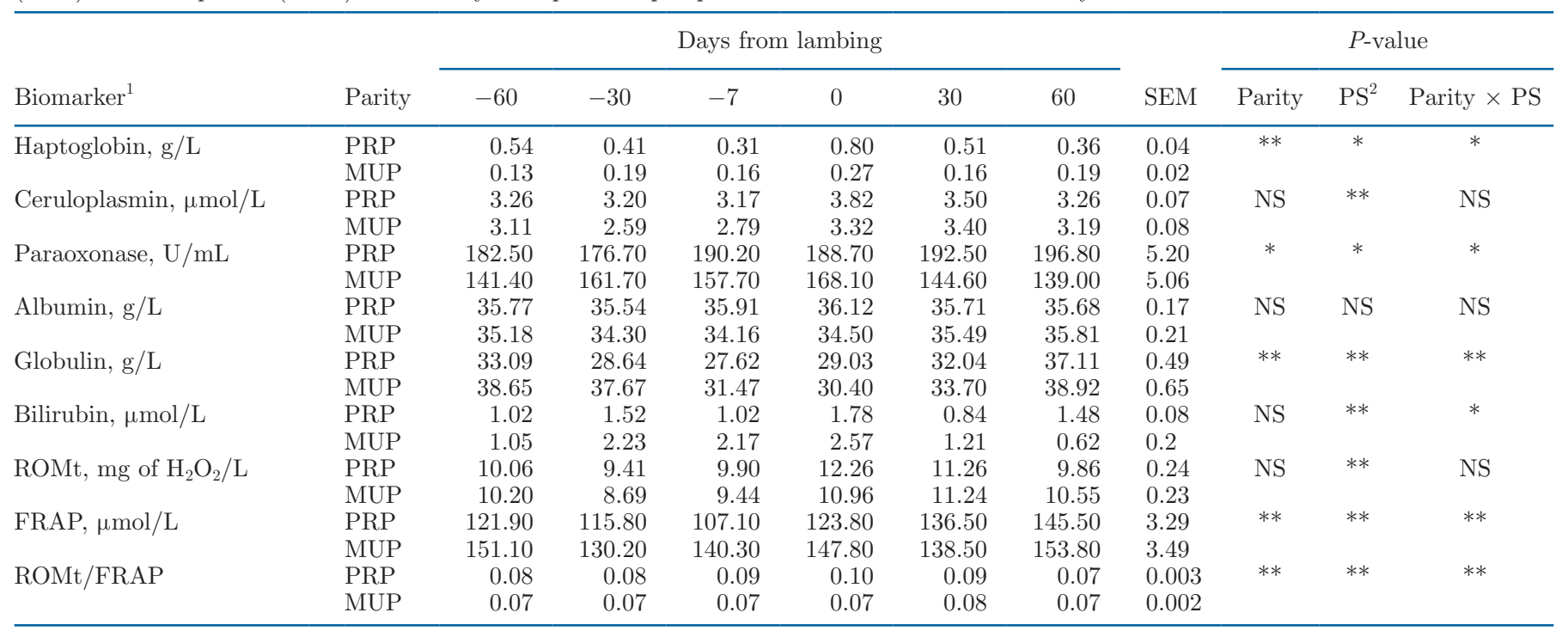

${ }^{1} \mathrm{ROMt}=$ reactive oxygen metabolites; FRAP $=$ ferric-reducing ability of plasma.

${ }^{2} \mathrm{PS}=$ physiological stage.

$* P<0.05$ and ${ }^{*} P<0.01$.

in PRP and MUP sheep (PS; $P<0.01$; Supplemental Figure S3, https://doi.org/10.3168/jds.2019-18114).

\section{Biomarkers of Inflammation and Oxidative Stress}

Positive $\boldsymbol{A P P}$. The plasma haptoglobin was higher in PRP sheep than MUP sheep (0.49 vs. $0.18 \mathrm{~g} / \mathrm{L} ; P<$ 0.01 ) for the overall period. At lambing time, the peak was observed in both groups (PS; $P<0.05$ ), but the concentration was much higher in the PRP group (parity $\times$ PS; $P<0.01$; Table 4). The plasma ceruloplasmin was not affected by parity number, but its activity increased after lambing, regardless of parity number (PS; $P<0.05$; Supplemental Figure S4, https://doi.org/10 $.3168 /$ jds.2019-18114).

Negative APP. The activity of PON proved to be higher in PRP sheep than in MUP sheep (187.90 vs. $152.11 \mathrm{U} / \mathrm{mL} ; P<0.05$; average over time). The MUP sheep showed a reduction in PON activity after lambing, whereas the activity in the PRP sheep remained almost constant (parity $\times$ PS; $P<0.05$ ).

The plasma concentration of albumin was not affected by parity or the PS. Conversely, the plasma globulin concentration was higher in MUP sheep for the whole period $(P<0.01)$ than in PRP sheep. In the last 2 mo of pregnancy, the concentration of globulin progressively decreased in both groups, reaching the lowest value at lambing time, but it increased thereaf- ter (Supplemental Figure S5, https://doi.org/10.3168/ jds.2019-18114). The MUP sheep showed a more severe reduction before lambing time. Both the PS and parity $\times$ PS interaction proved to be significant $(P<0.01)$.

The plasma bilirubin increased progressively in late pregnancy until lambing time and then decreased. The increase before lambing time and the resultant reduction were more pronounced in MUP sheep. Therefore, the effect of the PS $(P<0.01)$ and the parity $\times$ PS interaction $(P<0.05)$ was obtained (Table 4$)$.

Oxidative Stress. The plasma ROMt content was not affected by parity number (Table 4 ). The concentration of ROMt changed with the PS in both groups $(P<$ 0.01 ) in a similar manner; in particular, it progressively increased until lambing time and slightly decreased thereafter. Overall, the plasma FRAP content proved to be lower in the PRP group than in the MUP one (parity; $P<0.01$; Supplemental Figure S6, https://doi .org/10.3168/jds.2019-18114). The FRAP concentration remained almost constant in MUP ewes throughout the period, whereas it increased after lambing time in PRP ewes (parity $\times$ PS; $P<0.01$ ). The ROMt/FRAP ratio was higher in PRP sheep than MUP sheep (parity; $P<0.01$ ). In both groups, this index was affected by the PS $(P<0.01)$, mainly due to the temporary increase around lambing. However, the PRP group had a higher ROMt/FRAP ratio at lambing time than the MUP group (parity $\times$ PS; $P<0.01$ ). 


\section{DISCUSSION}

As in dairy cows, the transition period in dairy sheep represents a critical phase. To our knowledge, not enough data are available in the literature on the feeding behavior and inflammometabolic adaptation during the transition period of dairy ewes with different parity numbers reared in an extensive system. Previous studies mainly focused on a few blood parameters (Braun et al., 2010; Castillo et al., 2016; Lotfollahzadeh et al., 2016), together with the feed intake and energy balance. In our experiment, we investigated the effect of different parity numbers during the peripartum period on blood biomarkers related to energy-protein metabolism and the adaptive response of the innate immune system measured as inflammatory and oxidative stress biomarkers in pasture-based dairy ewes.

\section{Animal Performance: Energy and Protein Balance in Dairy Ewes}

The DMI increased in the last month of pregnancy and peaked at $30 \mathrm{~d}$ after lambing in both groups, according to the different nutritional requirements (Bocquier et al., 1993). The levels of DMI in both PRP and MUP sheep were consistent with the predicted values previously published (Pulina et al., 2013). The negative balance in terms of MP at $60 \mathrm{~d}$ after lambing in the PRP group was in agreement with the worsening of herbage quality due to the phenological stage. Both the BW and BCS profiles were in line with the findings of Gonzáles-García et al. (2015); the BW was higher in the MUP group than the PRP group, but the BCS was lower. This latter finding is in agreement with findings in dairy cows in grazing conditions (Adrien et al., 2012), where PRP cows were characterized by a higher BCS in the prepartum period. However, this condition was strongly affected by nutritional management. In our study, attempting to justify the BCS differences was difficult because monitoring of the MUP and PRP ewes started at $-60 \mathrm{~d}$ from lambing with a different BCS, which was maintained throughout the entire trial. However, the slight decrease of the BCS in MUP sheep compared with PRP sheep between 0 and $30 \mathrm{~d}$ of lactation (the PRP sheep did not undergo a reduction in the BCS) did not affect the hepatic and metabolic condition of MUP ewes as it did PRP ewes; this was highlighted by the lack of a difference at $30 \mathrm{~d}$ for the FFA, BHB, albumin, and ceruloplasmin.

\section{Energy and Protein Metabolism}

The higher glucose concentration found during pregnancy in PRP sheep in comparison with MUP sheep was in line with the higher ME index and lower twinship rate observed in the PRP group, as previously found by Bizelis et al. (2000), Charismiadou et al. (2000), and Mazur et al. (2009). A recent paper (Berlinguer et al., 2020) underlined the fact that the blood glucose level in pregnant Sarda dairy sheep decreased with the number of fetuses and increased with the energy intake. This metabolic condition of PRP ewes agreed with the higher BCS level before lambing and the lower twinship rate after lambing compared with the MUP group, but with a similar ratio between the total litter size and the dams' metabolic weight at lambing.

The difference between parity number groups in terms of blood glucose content disappeared after lambing, suggesting that the energy and protein balance improved in MUP ewes and worsened in PRP ewes. This condition was supported by the higher feed intake and the better fulfillment of requirements (e.g., higher $\triangle \mathrm{ME}$ and $\triangle \mathrm{MP}$ in MUP ewes than in PRP ewes) observed after lambing in the MUP ewes. All these conditions confirmed the better energy balance in MUP sheep after lambing, probably because these ewes were able to increase their feed intake more after lambing.

The BHB concentration peaked in the plasma the week before lambing, but only in PRP sheep. Nevertheless, the increase of BHB, in comparison with dairy cows, occurred before parturition (Ospina et al., 2010; Trevisi et al., 2011), confirming that the critical point for energy balance regulation is approximately 1 to 2 wk before lambing. The minimum concentration of plasma cholesterol was detected at lambing, when the energy deficiency reached its peak. Abd-Alla (2013) observed a higher value of blood cholesterol in PRP ewes than in MUP ewes and reasoned that the findings were due to the higher feed intake. The lower plasma triglyceride concentration observed in MUP ewes during gestation compared with PRP ewes, suggested that these ewes received a restricted diet in accordance with their requirements, and probably, also, that they had a lower concentration of circulating very-low-density lipoproteins, the lipoprotein fraction richer in triglycerides (Mazur et al., 2009).

As already underlined, MUP ewes received before lambing a low-quality hay in terms of protein content in comparison with PRP ewes. To cope with the lack of energetic substrates, MUP ewes likely mobilized their body proteins, and this would explain their higher plasma urea concentrations before lambing. Conversely, after lambing the highest plasma urea concentration was observed in PRP ewes, in agreement with the negative $\Delta \mathrm{MP}$, which was probably worsened by the higher mobilization of amino acids from body reserves for glycogenic purposes. The changes in plasma creatinine confirmed the reduction of body mass after lambing, as 
has also been observed in dairy cows (Caldeira et al., 2007), but no differences emerged among parity groups.

\section{Liver Function}

Overall, in this study, we found higher GGT activity in dairy sheep compared with dairy cows (Bionaz et al., 2007; Abeni et al., 2012; Brscic et al., 2015). These variations reflect a high transamination activity, which could have been affected by a specific physiological state, such as growth, inflammation, or a negative energy balance (Kaneko, 1986), when a relevant amount of amino acids could be used for gluconeogenesis. In our experiment, the highest GGT plasma activity in PRP ewes could have been related to the higher concentration of haptoglobin compared with MUP ewes, which signaled the presence of inflammatory processes.

\section{Inflammation}

Overall, the plasma concentration of positive APP (haptoglobin and ceruloplasmin) had a pattern of changes similar to those reported in dairy cows, peaking at lambing time (Bertoni and Trevisi, 2013). This suggested that events occurring in this period affected the innate immunity even in dairy ewes. Haptoglobin showed the most important differences between MUP and PRP ewes. In particular, the increase at lambing time proved to be less pronounced and less prolonged in MUP ewes than in PRP ewes. These data support the presence of an exacerbated immunity challenge in younger ewes around lambing time, as was observed previously in cattle (Mezzetti et al., 2019).

Compared with that of dairy cows around calving, the PON activity found in our study for both MUP and PRP sheep was approximately twice as high (Bionaz et al., 2007). Its activity decreased after lambing in the MUP group, similar to what happens with dairy cows (Bionaz et al., 2007). An opposite trend was observed in the PRP group, where subclinical inflammatory processes were exacerbated and prolonged. This seems to contrast with the pattern observed in dairy cows by Bertoni and Trevisi (2013). Nevertheless, to our knowledge, this is the first time that PON was measured in dairy ewes, and differences among parity groups could also reflect different levels of plasma lipoproteins or different levels of enrichment of this enzyme by the high-density lipoprotein fraction (Trevisi et al., 2012). Indeed, the variation of other negative APP or related parameters (Trevisi and Minuti, 2018), such as albumin, cholesterol as an index of lipoproteins, and bilirubin as an index of the enzymes necessary for the clearance, does not support a reduction of liver function. In addi- tion, the higher plasma concentration of negative APP and related parameters in PRP ewes throughout the experimental period, as well as the lower concentration of globulin, suggests a better liver function than in the MUP ewes (Bertoni and Trevisi, 2013). Thus, apparently, younger sheep appear to be more affected by the inflammatory process (haptoglobin and PON basis) than MUP sheep, although these results need to be confirmed in the future.

\section{Oxidative Stress}

The lack of references in dairy sheep with regard to ROMt and FRAP concentrations makes it difficult to establish whether and when these animals were experiencing oxidative stress. The ROMt concentration around lambing was similar to or lower than that reported in dairy cows (Trevisi et al., 2009, 2010). The high values of ROMt at lambing were probably due to an increased stress status during lambing, as observed in cows by Bernabucci et al. (2005), but they could also be interpreted as an increase of metabolic activity in cells. In the plasma, the ROMt/FRAP ratio increased around lambing in PRP ewes compared with MUP ewes, confirming the higher availability of total antioxidants in MUP ewes and, thus, the higher risk of oxidative stress in PRP ewes (Celi, 2010). The increased ROMt/ FRAP ratio in the PRP group seems also linked to the more severe inflammatory status already discussed in these animals and is supported by the higher release of positive APP (Trevisi and Minuti, 2018). The higher activity of FRAP in PRP ewes was probably due to the rise of stress level in young sheep compared with MUP ewes (Sevi et al., 2000). The increase of FRAP from lambing up to $60 \mathrm{~d}$ after lambing was dramatically higher for the PRP group $(+30 \%)$ than for the MUP one $(+9 \%)$. Comparing our results with those of Sevi et al. (2000), we observed that the PRP sheep probably had a less favorable milk secretion status than the MUP sheep, with a consequent exposure to subclinical mastitis, in agreement with the SCC content (higher in the PRP group than the MUP group). In fact, as reported by Rosati et al. (2005) and Casu et al. (2010), the risk of mastitis in dairy ewes increased with the SCC; in addition, an increase in the SCC was associated with the impairment of udder health (in terms of udder infection, e.g., Staphylococcus spp.) in dairy sheep, as reported by Leitner et al. (2004) and Contreras et al. (2007). In our study, the higher blood activity of ROMt and FRAP likely suggests that young sheep are characterized by a greater oxidative stress than MUP sheep, and this is partly supported by the inflammatory conditions in the udder. 


\section{CONCLUSIONS}

The results of this study provide a pattern of changes in the energy and protein biomarkers of healthy dairy ewes with different parity numbers that were grazing part time during the transition period. Based on differences in MY and quality as well as in BW and nutrient requirements between MUP and PRP sheep, a different feeding strategy could be applied during late pregnancy, thereby improving the inflammometabolic adaptations. In our experiment, we came across no relevant health issues, although the PRP group showed an altered inflammatory profile from late pregnancy. In fact, we found a higher level of haptoglobin, a key biomarker in the APP response, suggesting the presence of continuous challenges to the immune system and the metabolic adaptive system. On the other hand, MUP ewes had higher BW, SMY, and levels of milk protein, fat, and CN than PRP ewes, suggesting that a different and adequate feeding strategy (approximating the fulfillment of energy and protein requirements) is needed during the transition period for sheep in gestation to prevent metabolic disorders around the lambing period and ensure a good milking season. These first results could help to establish future threshold reference values of stress indicators in periparturient sheep of different orders of parity.

\section{ACKNOWLEDGMENTS}

The authors thank S. Picconi, A. Pintadu, G. Camoglio, R. Mura, and M. Ruiu (Agris Sardegna, Agricultural Research Agency of Sardinia) for the care given to the ewes and for their help in the milk and blood sampling, as well as G. Scanu, M. Niolu, A. Sanna, and M. Delrio (Agris, Agricultural Research Agency of Sardinia, Loc. Bonassai), and A. Ferrari (Department of Animal Science, Food and Nutrition, Piacenza) for the laboratory analyses. The authors have no conflict of interest in producing this document.

\section{REFERENCES}

Abd-Allah, M. 2013. Effects of parity and nutrition plane during late pregnancy on metabolic responses, colostrum production and lamb output of Rahmani ewes. Egypt. J. Anim. Prod. 50:132-142. https: //doi.org/10.21608/EJAP.2013.93673.

Abeni, F., L. Calamari, L. Stefanini, and L. G. Pirlo. 2012. Effect of average daily gain on body size, metabolism, and milk production of Italian Holstein heifers raised on two different planes of nutrition and calving at two different ages. Livest. Sci. 149:7-17. https: //doi.org/10.1016/j.livs.ci.2012.06.003.

Acuti, G., M. Trabalza-Marinucci, M. Cagiola, M. Pela, G. Curina, and L. Moscati. 2012. Extruded linseed supplementation in the diet of dairy sheep: The effects on immune response and oxidative stress as affected by the physiological state. Small Rumin. Res.
106 (Suppl):S21-S28. https://doi.org/10.1016/j.smallrumres.2012 .04 .029$.

Adrien, M. L., D. A. Mattiauda, V. Artegoitia, M. Carriquiry, G. Motta, O. Bentancur, and A. Meikle. 2012. Nutritional regulation of body condition score at the initiation of the transition period in primiparous and multiparous dairy cows under grazing conditions: Milk production, resumption of post-partum ovarian cyclicity and metabolic parameters. Animal 6:292-299. https://doi.org/ 10.1017/S175173111100142X.

AOAC International. 2000. Official Methods of Analysis. 17th ed. AOAC International, Gaithersburg, MD.

Bailey, R. W. 1958. The reaction of pentoses with anthrone. Biochem. J. 68:669-672. https://doi.org/http://doi.org/10.1042/bj0680669.

Berlinguer, F., C. Porcu, G. Molle, A. Cabiddu, M. Dattena, M. Gallus, V. Pasciu, S. Succu, F. D. Sotgiu, P. Paliogiannis, S. Sotgia, A. A. Mangoni, A. Gonzalez-Bulnes, C. Carru, and A. Zinellu. 2020. Circulating concentrations of key regulators of nitric oxide production in undernourished sheep carrying single and multiple fetuses. Animals (Basel) 10:65. https://doi.org/10.3390/ani10010065.

Bernabucci, U., B. Ronchi, N. Lacetera, and A. Nardone. 2005. Influence of body condition score on relationships between metabolic status and oxidative stress in periparturient dairy cows. J. Dairy Sci. 88:2017-2026. https://doi.org/10.3168/jds.S0022 -0302(05)72878-2.

Bertoni, G., and E. Trevisi. 2013. Use of the liver activity index and other metabolic variables in the assessment of metabolic health in dairy herds. Vet. Clin. North Am. Food Anim. Pract. 29:413-431. https://doi.org/10.1016/j.cvfa.2013.04.004.

Bionaz, M., E. Trevisi, L. Calamari, F. Librandi, A. Ferrari, and G. Bertoni. 2007. Plasma paraoxonase, health, inflammatory conditions, and liver function in transition dairy cows. J. Dairy Sci. 90:1740-1750. https://doi.org/10.3168/jds.2006-445.

Bizelis, J. A., M. A. Charismiadou, and E. Rogdakis. 2000. Metabolic changes during the perinatal period in dairy sheep in relation to level of nutrition and breed. II. Early lactation. J. Anim. Physiol. Anim. Nutr. (Berl.) 84:73-84. https://doi.org/10.1046/j.1439-0396 .2000.00283.x.

Bocquier, F., F. Barillet, P. Guillouet, and M. Jacquin. 1993. Prediction of energetic content of ewe's milk from different chemical analyses: Proposal for a standard milk for dairy ewes. Ann. Zootech. 42:57-66.

Bocquier, F., M. Theriez, S. Prache, and A. Brelurut. 1988. L'alimentation des ovins. Page 470 in Alimentation des Bovins, Ovins et Caprins. R. Jarrige, ed. INRA Publications, Versailles, France.

Braun, J. P., C. Trumel, and P. Bézille. 2010. Clinical biochemistry in sheep: A selected review. Small Rumin. Res. 92:10-18. https://doi .org/10.1016/j.smallrumres.2010.04.002.

Brscic, M., G. Cozzi, I. Lora, A. L. Stefani, B. Contiero, L. Ravarotto, and F. Gottardo. 2015. Short communication: Reference limits for blood analytes in Holstein late-pregnant heifers and dry cows: Effects of parity, days relative to calving, and season. J. Dairy Sci. 98:7886-7892. https://doi.org/10.3168/jds.2015-9345.

Calamari, L., A. Ferrari, A. Minuti, and E. Trevisi. 2016. Assessment of the main plasma parameters included in a metabolic profile of dairy cow based on Fourier Transform mid-infrared spectroscopy: Preliminary results. BMC Vet. Res. 12:4. https://doi.org/10.1186/ s12917-015-0621-4.

Caldeira, R. M., A. T. Belo, C. C. Santos, M. I. Vazques, and A. V. Portugal. 2007. The effect of body condition score on blood metabolites and hormonal profiles in ewes. Small Rumin. Res. 68:233-241. https://doi.org/10.1016/j.smallrumres.2005.08.027.

Cannas, A., L. O. Tedeschi, D. G. Fox, A. N. Pell, and P. J. Van Soest. 2004. A mechanistic model for predicting the nutrient requirements and feed biological values for sheep. J. Anim. Sci. 82:149 169. https://doi.org/10.2527/2004.821149x.

Castillo, C., A. Abuelo, and J. Hernández. 2016. Usefulness of metabolic profiling in the assessment of the flock's health status and productive performance. Small Rumin. Res. 142:28-30. https://doi .org/10.1016/j.smallrumres.2016.02.019. 
Casu, S., S. Sechi, S. L. Salaris, and A. Carta. 2010. Phenotypic and genetic relationships between udder morphology and udder health in dairy ewes. Small Rumin. Res. 88:77-83. https://doi.org/10 .1016/j.smallrumres.2009.12.013.

Celi, P. 2010. The role of oxidative stress in small ruminants' health and production. Rev. Bras. Zootec. 39(Suppl):348-363. https://doi .org/10.1590/S1516-35982010001300038.

Charismiadou, M. A., J. A. Bizelis, and E. Rogdakis. 2000. Metabolic changes during the perinatal period in dairy sheep in relation to level of nutrition and breed. I. Late pregnancy. J. Anim. Physiol. Anim. Nutr. (Berl.) 84:61-72. https://doi.org/10.1046/j.1439-0396 .2000.00282.x.

Contreras, A., D. Sierra, A. Sànchez, J. C. Corrales, J. C. Marco, M. J. Paape, and C. Gonzalo. 2007. Mastitis in small ruminants. Small Rumin. Res. 68:145-153. https://doi.org/10.1016/j.smallrumres 2006.09.011.

Crookenden, M. A., A. Heiser, A. Murray, V. S. R. Dukkipati, J. K. Kay, J. J. Loor, S. Meier, M. D. Mitchell, K. M. Moyes, C. G. Walker, and J. R. Roche. 2016. Parturition in dairy cows temporarily alters the expression of genes in circulating neutrophils. J. Dairy Sci. 99:6470-6483. https://doi.org/10.3168/jds.2015-10877.

Descalzo, A. M., E. M. Insani, A. Biolatto, A. M. Sancho, P. T. García, N. A. Pensel, and J. A. Josifovich. 2005. Influence of pasture or grain-based diets supplemented with vitamin $\mathrm{E}$ on antioxidant/ oxidative balance of Argentine beef. Meat Sci. 70:35-44. https:// doi.org/10.1016/j.meatsci.2004.11.018.

Drackley, J. K., H. M. Dann, N. Douglas, N. A. Janovick Guretzky, N. B. Litherland, J. P. Underwood, and J. J. Loor. 2005. Physiological and pathological adaptations in dairy cows that may increase susceptibility to periparturient diseases and disorders. Ital. J. Anim. Sci. 4:323-344. https://doi.org/10.4081/ijas.2005.323.

European Commission. 2010. Directive 2010/63/EU of the European parliament and of the council of 22 September 2010 on the protection of animals used for scientific purposes. Off. J. L. 276:33-79.

Gatellier, P., Y. Mercier, and M. Renerre. 2004. Effect of diet finishing mode (pasture or mixed diet) on antioxidant status of Charolais bovine meat. Meat Sci. 67:385-394. https://doi.org/10.1016/j .meatsci.2003.11.009.

González-García, E., A. Tesniere, S. Camous, F. Bocquier, F. Barillet, and P. Hassoun. 2015. The effects of parity, litter size, physiological state, and milking frequency on the metabolic profile of Lacaune dairy ewes. Domest. Anim. Endocrinol. 50:32-44. https:/ /doi.org/10.1016/j.domaniend.2014.07.001.

Heller, M. C., and J. L. Johns. 2015. Acute phase proteins in healthy goats: Establishment of reference intervals. J. Vet. Diagn. Invest. 27:177-181. https://doi.org/10.1177/1040638715575750.

Kaneko, J. J. 1986. Recent trends in clinical pathology and hematology. In the Proceedings of the 4th International Symposium Veterinary Laboratory Diagnosticians, Amsterdam, the Netherlands. G. H. A. Borst, ed. Iowa State University Press, Ames.

Lacetera, N., D. Scalia, U. Bernabucci, B. Ronchi, D. Pirazzi, and A. Nardone. 2005. Lymphocyte functions in overconditioned cows around parturition. J. Dairy Sci. 88:2010-2016. https://doi.org/10 .3168/jds.S0022-0302(05)72877-0.

Leitner, G., M. Chaffer, A. Shamay, F. Shapiro, U. Merin, E. Ezra, A. Saran, and N. Silanikove. 2004. Changes in milk composition as affected by subclinical mastitis in sheep. J. Dairy Sci. 87:46-52. https://doi.org/10.3168/jds.S0022-0302(04)73140-9.

Licitra, G., T. M. Hernandez, and P. J. Van Soest. 1996. Standardization of procedures for nitrogen fractionation of ruminant feeds. Anim. Feed Sci. Technol. 57:347-358. https://doi.org/10.1016/ 0377-8401(95)00837-3.

Loor, J. J., G. Bertoni, A. Hosseini, J. R. Roche, and E. Trevisi. 2013. Functional welfare - Using biochemical and molecular technologies to understand better the welfare state of peripartal dairy cattle. Anim. Prod. Sci. 53:931-953. https://doi.org/10.1071/AN12344.

Lopreiato, V., A. Minuti, F. Trimboli, D. Britti, V. M. Morittu, F. P. Cappelli, J. J. Loor, and E. Trevisi. 2019. Immunometabolic status and productive performance differences between periparturient Simmental and Holstein dairy cows in response to pegbovi- grastim. J. Dairy Sci. 102:9312-9327. https://doi.org/10.3168/jds .2019-16323.

Lotfollahzadeh, S., A. Zakian, M. Tehrani-Sharif, and D.G. Watson. 2016. Assessment the alterations of some biochemical parameters in Afshari sheep with possible metabolic disorders. Small Rumin. Res. 145:58-64. https://doi.org/10.1016/j.smallrumres.2016.10 .012 .

Matanovic, K., K. Severin, F. Martinković, M. Šimpraga, Z. Janicki, and J. Barišić. 2007. Hematological and biochemical changes in organically farmed sheep naturally infected with Fasciola hepatica. Parasitol. Res. 101:1657-1661. https://doi.org/10.1007/s00436 -007-0709-2.

Mavrogianni, V. S., and C. Brozos. 2008. Reflections on the causes and the diagnosis of peri-parturient losses of ewes. Small Rumin. Res. 76:77-82. https://doi.org/10.1016/j.smallrumres.2007.12.019.

Mazur, A., M. Ozgo, and Y. Rayssiguier. 2009. Altered plasma triglyceride-rich lipoproteins and triglyceride secretion in feed-restricted pregnant ewes. Vet. Med. (Praha) 54:412-418. https://doi.org/10 .17221/77/2009-VETMED.

Mezzetti, M., F. Piccioli-Cappelli, P. Bani, M. Amadori, L. Calamari, A. Minuti, J. J. Loor, M. Bionaz, and E. Trevisi. 2019. Monensin controlled-release capsule administered in late-pregnancy differentially affects rumination patterns, metabolic status, and cheesemaking properties of the milk in primiparous and multiparous cows. Ital. J. Anim. Sci. 18:1271-1283. https://doi.org/10.1080/ 1828051X.2019.1645623.

Minuti, A., N. Jahan, V. Lopreiato, F. Piccioli-Cappelli, L. Bomba, S. Capomaccio, J. J. Loor, P. Ajmone-Marsan, and E. Trevisi. 2020. Evaluation of circulating leukocyte transcriptome and its relationship with immune function and blood markers in dairy cows during the transition period. Funct. Integr. Genomics 20:293-305. https://doi.org/10.1007/s10142-019-00720-0.

Molle, G. 2014. Ingestive behaviour and performances of dairy ewes part-time grazing Mediterranean pastures. $\mathrm{PhD}$ thesis. University of Sassari, Sassari, Italy.

NRC. 2007. Nutrient Requirements of Small Ruminants: Sheep, Goats, Cervids, and New World Camelids. National Academies Press, Washington, DC.

Ospina, P. A., D. V. Nydam, T. Stokol, and T. R. Overton. 2010. Evaluation of nonesterified fatty acids and $\beta$-hydroxybutyrate in transition dairy cattle in the northeastern United States: Critical thresholds for prediction of clinical diseases. J. Dairy Sci. 93:546554. https://doi.org/10.3168/jds.2009-2277.

Pulina, G., M. Avondo, G. Molle, A. H. D. Francesconi, A. S. Atzori, and A. Cannas. 2013. Models for estimating feed intake in small ruminants. Rev. Bras. Zootec. 42:675-690. https://doi.org/ 10.1590/S1516-35982013000900010.

Rosati, R., G. Militello, C. Boselli, G. Giangolini, G. Brajon, M. Casini, M. Scatassa, P. Bono, A. Cannas, G. Mugoni, G. Denti, S. Gradassi, and A. Fagiolo. 2005. Cellule somatiche nel latte ovino e caprino: Definizione del valore medio nazionale e del valore fisiologico. Sci. Tec. Latt. Casearia 56:3.

Saleh, M. A. 2008. Circulating oxidative stress status in desert sheep naturally infected with Fasciola hepatica. Vet. Parasitol. 154:262269. https://doi.org/10.1016/j.vetpar.2008.03.012.

Sevi, A., L. Taibi, M. Albenzio, A. Muscio, and G. Annicchiarico. 2000. Effect of parity on milk yield, composition, somatic cell count, renneting parameters and bacteria counts of Comisana ewes. Small Rumin. Res. 37:99-107. https://doi.org/10.1016/ S0921-4488(99)00133-9.

Tedeschi, L. O., A. Cannas, and D. G. Fox. 2008. A nutrition mathematical model to account for dietary supply and requirements of energy and nutrients for domesticated small ruminants: The development and evaluation of the Small Ruminant Nutrition System. Rev. Bras. Zootec. 37(spe):178-190. https://doi.org/10.1590/ S1516-35982008001300020.

Todaro, M., M. Dattena, A. Acciaioli, A. Bonanno, G. Bruni, M. Caroprese, M. Mele, A. Sevi, and M. T. Marinucci. 2015. A seasonal sheep and goat milk production in the Mediterranean area: 
Physiological and technical insights. Small Rumin. Res. 126:59-66. https://doi.org/10.1016/j.smallrumres.2015.01.022.

Trevisi, E., M. Amadori, I. Archetti, N. Lacetera, and G. Bertoni. 2011. Inflammatory response and acute phase proteins in the transition period of high-yielding dairy cows. Pages 355-380 in Acute Phase Proteins as Early Non-Specific Biomarkers of Human and Veterinary Diseases. F. Veas, ed. InTech, Rijeka, Croatia.

Trevisi, E., G. Bertoni, P. Risè, and C. Galli. 2009. Changes of plasma fatty acids during inflammatory events in dairy cows. Prog. Nutr. 10-11:28-35.

Trevisi, E., P. Grossi, T. Bacchetti, G. Ferretti, and G. Bertoni. 2012. Variation factors of paraoxonase in blood and in HDL lipoproteins in dairy cow. Prog. Nutr. 14:43-49.

Trevisi, E., N. Jahan, G. Bertoni, A. Ferrari, and A. Minuti. 2015. Pro-inflammatory cytokine profile in dairy cows: Consequences for new lactation. Ital. J. Anim. Sci. 14:3862. https://doi.org/10 $.4081 /$ ijas.2015.3862.
Trevisi, E., and A. Minuti. 2018. Assessment of the innate immune response in the periparturient cow. Res. Vet. Sci. 116:47-54. https: //doi.org/10.1016/j.rvs.c.2017.12.001.

Trevisi, E., A. Zecconi, G. Bertoni, and R. Piccinini. 2010. Blood and milk immune and inflammatory profiles in periparturient dairy cows showing a different liver activity index. J. Dairy Res. 77:310317. https://doi.org/10.1017/S0022029910000178.

\section{ORCIDS}

A. Cabiddu () https://orcid.org/0000-0002-2077-4201

V. Lopreiato (1) https://orcid.org/0000-0001-6965-7340

A. Minuti (๑ https://orcid.org/0000-0002-0617-6571

E. Trevisi @ https://orcid.org/0000-0003-1644-1911 